\title{
Furuncular myiasis of the breast caused by the larvae of the Tumbu fly (Cordylobia anthropophaga) Charles Adeyinka Adisa* and Augustus Mbanaso
}

\author{
Address: Department of Surgery, Abia State University Teaching Hospital, Aba, Abia State, Nigeria \\ Email: Charles Adeyinka Adisa* - adisayinka@yahoo.com; Augustus Mbanaso - ausymbanaso@yahoo.com \\ * Corresponding author
}

Published: 29 February 2004

BMC Surgery 2004, 4:5
Received: 07 November 2003

Accepted: 29 February 2004

This article is available from: http://www.biomedcentral.com/I47I-2482/4/5

(C) 2004 Adisa and Mbanaso; licensee BioMed Central Ltd. This is an Open Access article: verbatim copying and redistribution of this article are permitted in all media for any purpose, provided this notice is preserved along with the article's original URL.

\begin{abstract}
Background: Cutaneous myiasis of the breast due to infestation by the larva of Cordylobia anthropophaga is rare. To the best of our knowledge, only one case has been reported in the English literature. This rarity calls for an awareness of its possibility as a cause of furuncular breast lesions, especially in areas where the $C$. anthropophaga (Tumbu fly) is endemic or in patients returning from such areas. As it can be easily confused with other furuncular breast lesions (like tuberculosis, mycosis, actinomycosis, furunculosis, chronic breast abscess and fungating malignancies), this awareness is important to avoid misdiagnosis or delay in diagnosis.

We present a case of furuncular breast myiasis due to the larvae of $C$. anthropophaga earlier misdiagnosed as mastitis in a patient living in tropical Africa (Nigeria) where the Tumbu fly is endemic.

Case presentation: We report a 70 year old woman who presented with a week history of itchy multiple discharging sinuses of the right breast. The sinuses contained wriggling larvae of $C$. anthropophaga. Fourteen larvae were extracted from the breast and the sinuses healed quite well after the extraction.

Conclusions: Cutaneous myiasis of the breast is rare, hence, an awareness of its clinical features is necessary when a patient presents with furuncular skin lesions especially in endemic areas or people returning from such areas. Diagnosis is mainly clinical and lesions heal well after the extraction of the larvae.
\end{abstract}

Preventive measures such as ironing after drying of dresses and a good personal hygiene are crucial in controlling $C$. anthropophaga infestation.

\section{Background}

Myiasis is the term applied to the infestation of live humans and vertebrate animals with the larvae (maggots) of Diptera (two winged) flies. In humans, infestation may affect the skin, wounds, intestines and body cavities (oral, nasal, aural, ocular, sinusal, vaginal and urethra) [1].
When open wounds are involved, the myiasis is known as traumatic and when boil-like, the lesion is termed furuncular. Cordylobia anthropophaga (also referred to as "Tumbu Fly", "Mango Fly", "Skin maggot fly or "Verde Cayor") is endemic in tropical Africa [2]. Furuncular myiasis as a result of Cordylobia anthropophaga infestation has been endemic in the West African sub region for more than 135 years [3]. 


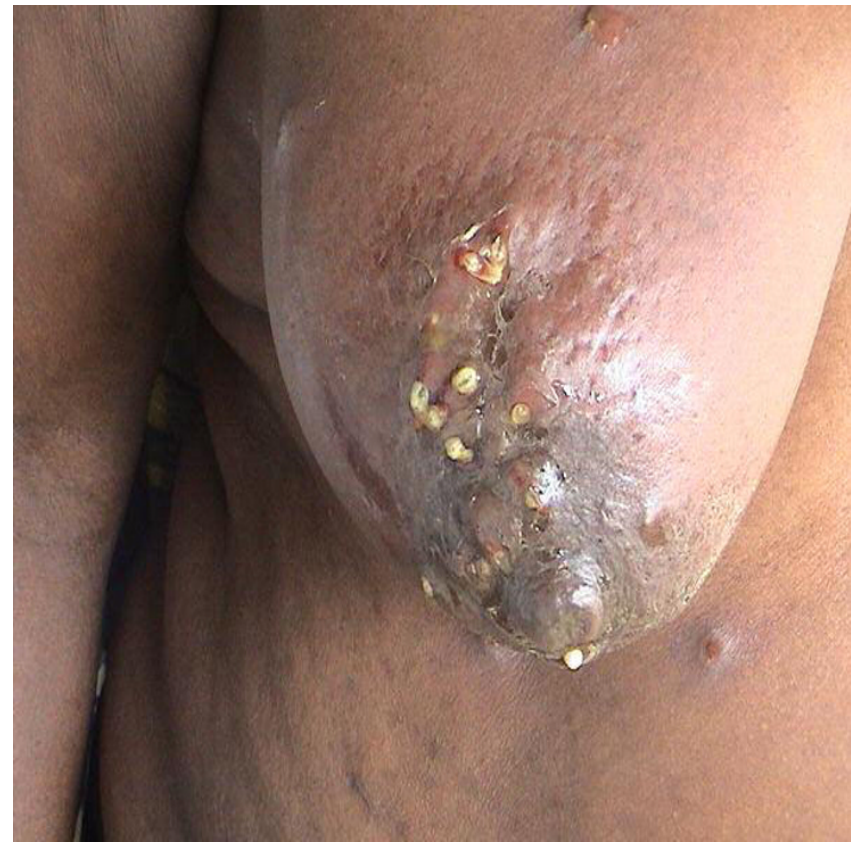

Figure I

Furuncular breast lesion with multiple sinuses containing Tumbu fly larvae.

The other flies that cause furuncular myiasis include Cordylobia rhodaini (Lund fly, found in the rainforest areas of tropical Africa) and Dermatobia hominis (human botfly, which is endemic in Central and South America).

The mode of transmission of Dermatobia hominis differs from the Cordylobia species. The eggs of D. hominis are carried to the host by a blood-sucking insect, such as mosquitoes and ticks and the hatched larvae invade exposed skin of the trunks, head and limbs. The eggs of Cordylobia species are however deposited on the soil or wet and soiled clothes hung outside for drying. The hatched larvae invade unexposed skin (of the buttocks, trunk, the limbs and penis) in contact with the wet clothes.

\section{Case Presentations}

A 70 yr old woman, resident in Aba (South East, Nigeria) referred to the surgery clinic of the Abia State University Teaching Hospital (Aba, Nigeria) with a week history of "multiple itchy, painful boils" of the right breast.

Pain and swelling of the right breast were so severe on the day of presentation that she was taken to the emergency unit of the hospital where a diagnosis of right breast mastitis was made before her referral to us. She often visits her village where the Tumbu fly is endemic. She usually spreads her washed dresses on a line near the bush and

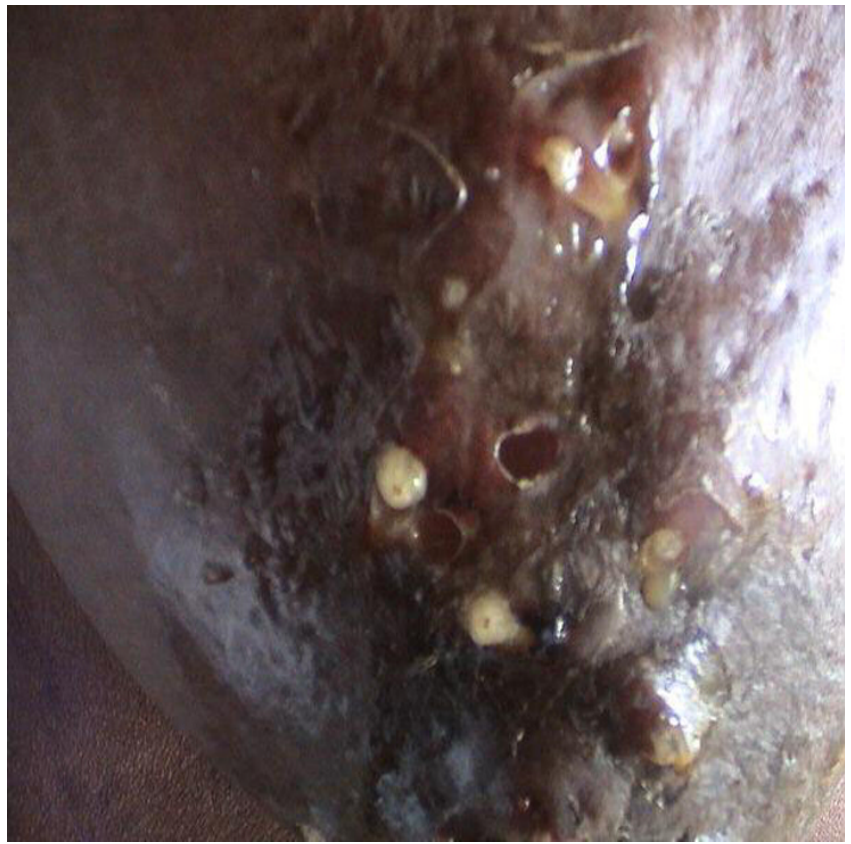

Figure 2

One of the sinuses after extraction of the Larva.

does not iron them before wearing them. Examination revealed a patient in severe painful distress, multiple discharging sinuses on the right breast and each sinus had a whitish object at the opening with some wriggling movement (Fig. 1 and 2).

The diagnosis of cutaneous myiasis of the right breast was made. Fourteen larvae were extracted from the affected area (Fig. 3, see additional movie file). They were identified as the larvae of Cordylobia anthropophaga by the parasitologist in the hospital. She was placed on ampicillin/ cloxacillin capsules, tetanus toxoid injection, analgesics and daily wound dressing with eusol. She was seen in the clinic a week later when all the furuncles had healed (Fig. 4 ). She has been doing well since then with no recurrence of the disease.

\section{Conclusions}

The first description of myiasis was by Hope in 1840 [4]. Many cases of myiasis affecting different human organs have been described since then [5-8]. Cutaneous myiasis of the breast is very rare, only few cases have been reported in the literature and the majority of them are due to the human botfly Dermatobia hominis [9-11]. To the best of our knowledge, only one case of breast myiasis due to $C$. anthropophaga has been reported in the literature, and interestingly from Nigeria, where this second case is being reported [12]. 


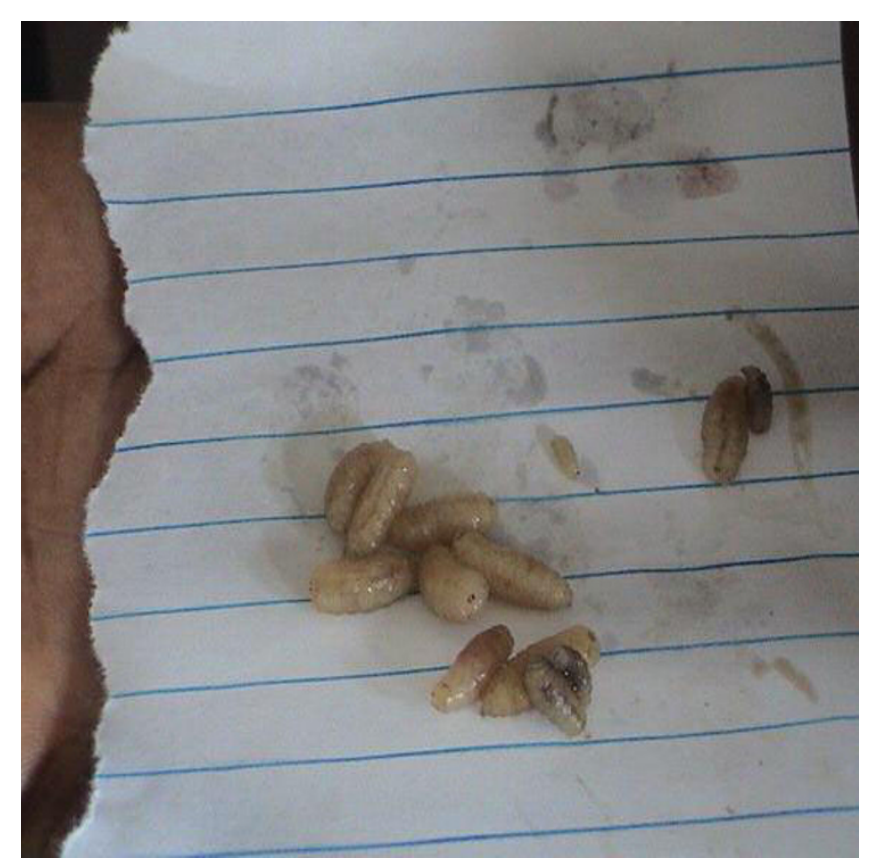

Figure 3

The extracted Tumbu fly Larvae.

C. anthropophaga is a large, robust brownish yellow fly found widely throughout tropical Africa. It deposits 100300 eggs on soil polluted with animal excrement or on clothing saturated with perspiration and soiled diapers. After hatching, the larvae can stay alive for seven to twenty days, while attached to contaminated articles and clothing or the soil. On contact with the skin of man or other vertebrates they easily penetrate the skin.

Dogs and small rodents are a particularly important reservoir for the parasite. Humans are infected only accidentally [12]. Diagnosis is mainly clinical. The main diagnostic features are recent travel to an endemic area, one or more non healing lesions on the skin, symptoms of pruritus, movement under skin or pain. Other features include serous or serosanguineous discharge from a central punctum and small, white thread-like structure protruding from the lesion. The diagnosis is confirmed by the extraction of the larvae $[13,14]$.

Differential diagnosis of furuncular myiasis of the breast includes furunculosis, actinomycosis, fungating carcinoma of the breast, tuberculosis of the breast and chronic ulcerating breast abscess. Others include periductal mastitis, inflammatory carcinoma of the breast and cellulitis [9].

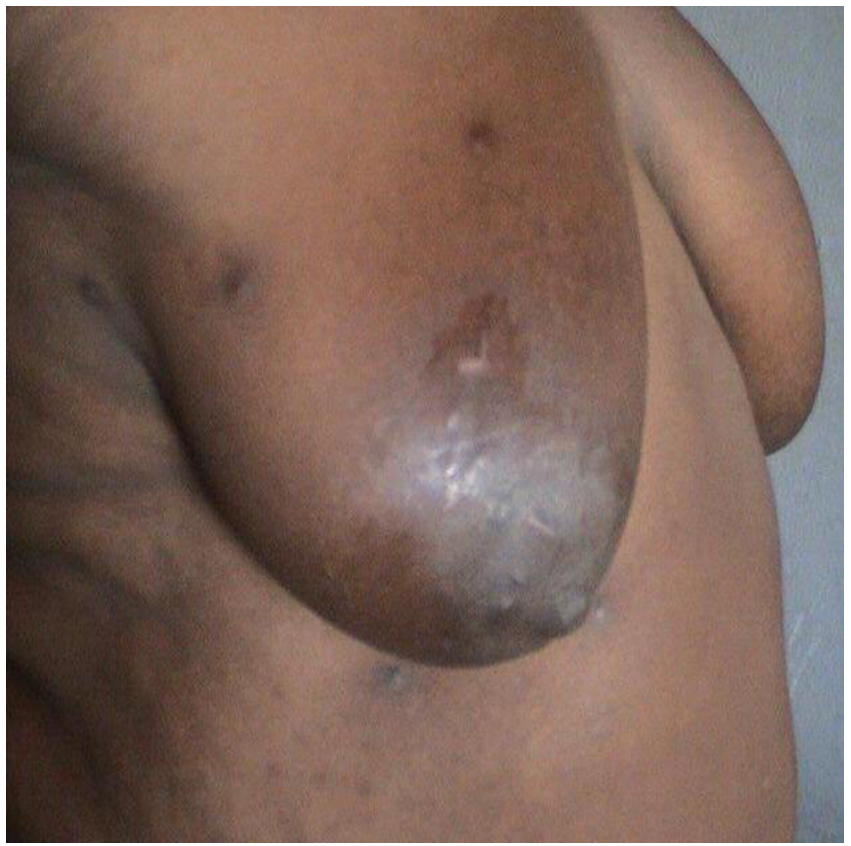

Figure 4

Healed skin one week after extraction of the Tumbu Fly larvae.

Diagnosis is usually established by the identification of the larva; however radiological investigations like mammography and ultrasonography may be helpful in the diagnosis of Dermatobia hominis. Mammographic features include ill defined masses and associated microcalcifications while ultrasonography may show hyper echoic mass representing the mass surrounded by an hypo echoic halo representing the cavity [9].

The goal of treatment is to remove the larva and treat any associated infection with antibiotics [9]. However, secondary bacteria infections are rare in C. anthrophaga infestations. The lesion heals rapidly after the larva is removed or it spontaneously exits. Complications include cellulitis, abscess formation, osteomyelitis and tetanus [12]. Methods of removing the larva include obstructing the cutaneous orifice thus suffocating the larva, which forces it to wriggle out. Substances used include oil, petroleum jelly, butter and liquid paraffin [9].

Forceps may also be used or an incision made over the boil after injecting a local anesthetic agent like lignocaine. This must be done carefully and the entire larva extracted as any remnant may provoke an inflammatory response. Another method is by applying mechanical pressure on either side of the furuncle, thus extruding the larva [15]. Boggild et al. recently described a new and effective 
method for extraction of $D$. hominis larvae using a snake venom extractor [16].

Cutaneous myiasis of the breast as a result of $C$. anthrophaga is an uncommon condition and an awareness of its clinical features is essential to avoid unnecessary delay in the diagnosis and treatment. General improvement of sanitation, personal hygiene and exterminating the flies by insecticides would also be helpful in prevention. Simple measures such as washing clothes thoroughly, drying and ironing of clothes are also necessary to reduce the risk of this human myiasis.

\section{Competing Interests}

None declared.

\section{Authors' Contributions}

CAA is the Principal and Corresponding Author. AM is the Head of the Unit and helped with the manuscript.

\section{Additional material}

\section{Additional File 1}

video clip showing how the larvae were extracted.

Click here for file

[http://www.biomedcentral.com/content/supplementary/1471-

2482-4-5-S1.mpg]

\section{Acknowledgements}

A written consent was obtained from the patient regarding publication of the patient's details.

\section{References}

I. Gursel M, Aldemir OS, Ozgur Z, Ataoglu A: A rare case of gingival myiasis caused by Diptera (Calliphoridae). I Clin Periodontol 2002, 29:777-80.

2. Veraldi S, Brusasco A, Suss : Cutaneous myiasis caused by larvae of Cordylobia anthropophaga (Blanchard). Int J Dermat 1993, 32: $184-182$.

3. Pampiglione $S$, Bettoli $V$, Cestari G, Staffa M: Furuncular myiasis due to Cordylobia anthropophaga, endemic in the same locality for over I 30 years. Ann Trop Med Parasit 1993, 87:2 I 9-220.

4. Hope FW: On insects and their larvae occasionally found in the human body. Trans R Soc Entomol 1840, 2:256-27I.

5. Erfan F: Gingival myiasis caused by Diptera (Sarcophaga). Oral Surg Oral Med Oral Pathol 1980, 49: I 48-I 50.

6. Edwards KM, Meredith TA, Hagler WS, Healy GR: Ophthalmomyiasis interna causing visual loss. Am J Opht 1984, 97:605-6I0.

7. Ferrar P: Aguide to the breeding habits and immature stages of Diptera Cyclorrhapha. Entomonograph 1987, 8:907.

8. Jiang C: A collective analysis on $\mathbf{5 4}$ cases of human myiasis in China from 1995-200 I. Chin Med J 2002, I I 5( I 0): I445- I 447.

9. Barros N, D'Avila MS, Bauab SP, Flávia KKI, Felipe JC, Su JK, MD Luciano FC, Issa FKK, Freitas FJC, Kim SJ, Chala LF, Cerri GG: Cutaneous Myiasis of the Breast: Mammographic and US Features-Report of Five Cases. Radiology 200I, 21 8:517-520.

10. Facina G, Nazario ACP, Kemp C, Gebrim LH, Lima GR: Myiasis by Dermatobia hominis mimicking periductal mastitis. Rev Bras Mastol 1999, 9:84-85.

II. Kahn DG: Myiasis secondary to Dermatobia hominis (human botfly) presenting as a long-standing breast mass. Arch Pathol Lab Med 1999, I 23:829-83I.
12. Ugwu BT, Nwadiaro PO: Cordylobia anthropophaga Mastitis mimicking Breast Cancer: Case Report. East Afr Med J 1999, 76:115-6.

13. Mashhood AA: Furuncular Myiasis by Tumbu Fly. J Coll Physicians Surg Pak 2003, I3(4): 195-7.

14. Purych D: Dermatobia-cutaneous myiasis, Bugs on the web. [http://www2.provlab.ab.ca/bugs/webbug/parasite/botdiag.htm].

15. Olumide Y: Cutaneous myiasis: a simple and effective technique for extraction of Dermatobia hominis larva. Int J dermatol 1994, 33:148-9.

16. Boggild AK, Keystone JS, Kain KC: Furuncular myiasis: a simple and rapid method for extraction of intact Dermatobia hominis larvae. Clin Infect Dis 2002, 35:336-8.

\section{Pre-publication history}

The pre-publication history for this paper can be accessed here:

http://www.biomedcentral.com/1471-2482/4/5/prepub

\section{Publish with Biomed Central and every scientist can read your work free of charge}

"BioMed Central will be the most significant development for disseminating the results of biomedical research in our lifetime."

Sir Paul Nurse, Cancer Research UK

Your research papers will be:

- available free of charge to the entire biomedical community

- peer reviewed and published immediately upon acceptance

- cited in PubMed and archived on PubMed Central

- yours - you keep the copyright

Submit your manuscript here:

http://www.biomedcentral.com/info/publishing_adv.asp
Biomedcentral 